\title{
CLINICAL EXPERIENCE WITH HEXYLCAINE HYDROCHLORIDE (CYCLAINE) *
}

R. A. Gondon, C.D., B.Sc., M.D., F.R.C.P.(C), F.F.A.R.C.S., D.A., F.A.C.A.*"

IN spite of the large number of effective local anaesthetic drugs already| available on the market, the search continues for drugs of greater potency and more prolonged action, with low toxicity and absence of tissue irritation. One of the latest substances to be presented for use as a local anaesthetic is Hexylcaine (Cyclaine).

Hexylcaine is 1-cyclohexylamino-2-propylbenzoate hydrochloride, and the structural formula is<smiles>CC(CNC1CCC(CCl)CC1)OC(=O)C1CCCCC1</smiles>

This substance was synthesized by Hancock and Cope, and described in 1944 (1). Evaluation as a local anaesthetic substance was done by Kuna and Seeler (2).

\section{Physical Properties}

Hexylcaine has a molecular weight of 297.85 . It is freely soluble in water to a concentration of 12 per cent, and is not altered by ordinary sterilizing procedures. The $\mathrm{pH}$ of a 1 per cent solution is 4.4 , as compared with $\mathrm{pH} 6.0$ for freshly prepared solutions of procaine, $\mathrm{HCl}$.

\section{Toxicity}

The toxicity of Hexylcaine was investigated in laboratory animals by Beyer et al. (3), and compared with Procaine, Neothesin, Cocaine, Butacaine, Tetracaine, and Dibucaine. The intravenous $L D_{50}$ was determined in mice, guinea pigs and rabbits, and on this basis the absolute toxicity appears to be about $\%$ that of cocaine, $\%$ that of Dibucaine (Nupercaine), and three times that of procaine. The subcutaneous $L D_{50}$ in guinea pigs when the drug was dissolved in $1 / 50,000$ epinephrine solution was $385 \mathrm{mg} / \mathrm{kg}$ as compared with $87 \mathrm{mg} / \mathrm{kg}$ for cocaine, $78 \mathrm{mg} / \mathrm{kg}$ for tetracaine (Pontocaine) and $500 \mathrm{mg} / \mathrm{kg}$ for procaine.

\section{Activity}

The activity of Hexylcaine was likewise investigated in laboratory animals by Beyer et al. (3). The activity was tested on the intact sciatic nerve of the guinea pig, and the $A_{100}$ for Hexylcaine was found to be $1 / 4$ of 1 per cent as compared to 1 per cent for procaine, ${ }_{12}$ of 1 per cent for cocaine and $1 / 8$ of 1 per cent for dibucaine. This drug is, therefore, four times as potent as procaine, twice as potent as cocaine, and half the potency of dibucaine. It was found, moreover,

"Presented to the Section of Anaesthesia, Canadran Medical Association, Vancouver, B.C., June 17, 1954.

* Department of Anaesthesia, University of Toronto and Toronto General Hospital.

Canad. Anaes. Soc. J., vol. 1, no. 1, July, 1954 
that any concentration of Hexylcaine which produced anaesthesia gave longer anaesthesia than that produced by 2 per cent procaine $\mathrm{HCl}$.

\section{Relative Toxicity}

Relating the toxicity figures to those for activity it is found that Hexylcaine has a therapeutic ratio more favourable than that of procaine (584 compared to 353 for procaine).

Spinal toxicity studies in animals have shown that the MLC for Hexylcaine is four times the active concentration (3). Activity studies with spinal anaesthesia in dogs gave a duration of anaesthesia roughly twice that with procaine.

\section{Clinical Application}

A number of reports have appeared in the literature recording most favourable data on the clinical use of Hexylcaine. All reports agree that this is a satisfactory agent for employment in regional infiltration and nerve block, spinal anaesthesia, and topical anaesthesia.

\section{Regional Anaesthesia}

The use of Hexylcaine in regional block anaesthesia has been reported by Hudon (4), Orkin and Rovenstine (5), and Crawford (6). These reports have been marked by unanimity with respect to the potency and usefulness of the drug, and the low incidence of toxic reactions in clinical use.

Personal experience with this drug began in March, 1952, when I commenced to intersperse therapeutic blocks done with Cyclaine amongst those done with procaine and metycaine, which I had been using for some years. The drug proved to be a most satisfactory local anaesthetic agent. Two factors stood out in comparison with the other two drugs mentioned: (1) the rapid onset and wider diffusion of the Cyclaine solution, and (2) a somewhat greater degree of tissue irritation, made evident by some persistent tenderness at the site of injection, which lasted sometimes for several days. The more rapid onset of a complete block was a decided advantage, and the tissue irritation was not so great as to be a real inconvenience to the patient. During the past year I have employed Cyclaine exclusively in my private practice, and since May of 1953 exclusively in those blocks which I personally have done about the hospital. All blocks have been done with the 1 per cent solution prepared by Sharpe \& Dohme, Inc. The drug has proved uniformly satisfactory in the production of anaesthesia. The following regional anaesthetic procedures have been recorded:

Procedure
Stellate ganglion block
Lumbar sympathetic block
Brachial plexus block
Caudal blocks
Other blocks (pudendal, sciatic,
femoral, popliteal, ulnar,
median, transverse scapular, vagal)

Average

amount used

$15 \mathrm{cc}$.

$20 \mathrm{cc}$.

Number

$30-40$ cc.

68

$25 \mathrm{cc}$.

3-30 cc.

41

18

4

37

Total blocks with Cyclaine 1 per cent 
No patient in this series has suffered a serious toxic reaction. Four patients only have complained of palpitations, or of feeling faint.

The only block which might be classed as a failure was a partial brachial plexus block, due to technical error, which was still adequate for the reduction of a Colles' fracture. In nearly eyery case the onset of complete anaesthesia or evidence of sympathetic block has been much more rapid than might have been expected following the use of procaine in a similar situation. We have had brachial plexus blocks which lasted more than four hours, and the caudal blocks have persisted for periods from $4^{1 / 2}$ to 5 hours. There have been no local complications at the site of injection.

\section{Spinal Anaesthesia}

Ruben and Anderson (7) in 1949 reported a series of 500 spinal ahaesthetics done with Hexylcaine. Torkelson and Cooley reported its use for spinal anaesthesia in 1,000 obstetrical deliveries, including 25 Caesarean sections. These latter authors report an incidence of post-spinal headache in this group of 3,6 per cent ( 36 patients). Hudon reported 64 spinal anaesthetics with the drug.

$U_{\mathrm{p}}$ to the present time we have used the drug thirteen times in spinal anaesthesia. Nine of these patients underwent Caesarean section, three transurethral resection of the prostate, and one reduction of a fractured femur. The drug has been used in a hyperbaric preparation containing $25 \mathrm{mg}$. per $\mathrm{cc}$. of the drug in 10 per cent glucose solution. For Caesarean sections $30 \mathrm{mg}$. has been used, expanded to 2 or $3 \mathrm{cc}$. with spunal fluid before injection, and well mixed. In four of the patients undergoing Caesarean section the head of the table was then lowered about 10 degrees until the anaesthesia reached the costal margin, when the table was tilted slightly in the foot-down position until the peritoneum was opened, when the table was either levelled or trendelenburged in accordance with the requirements of the surgeon. In one of these cases a vasopressor drug was given before the induction of spinal anaesthesia, and no blood pressure drop was recorded. In the others no vasopressor was given, and the blood pressure declined about $10 \mathrm{~mm}$. $\mathrm{Hg}$ on the average. In these four patients the anaesthesia outlasted the operation. In the fifth case for Caesarean section the head of the table was not lowered after the injection and anaesthesia to the costal margin resulted. However, anaesthesia became inadequate after 55 minutes and supplementation was required. I am inclined to believe that in this case the concentration of the solution at the upper levels was inadequate.

The patients who have had spinal anaesthesia with Hexylcaine for transurethral resection of the prostate have, with one exception, received a dose of $25 \mathrm{mg}$. in $1 \mathrm{cc}$. of glucose 10 per cent expanded to $2 \mathrm{cc}$. The foot of the table has then been lowered, concentrating the anaesthesia in the sacral region. One patient received $50 \mathrm{mg}$. expanded to 4 cc., and anaesthesia extended to the upper thorax.

From our present small experience, I would conclude that Hexylcaine is a very satisfactory drug for use in spinal anaesthesia.

\section{Topical Anaesthesia}

Published reports by Orkin and Rovenstine (5), Ray and Vinson (8), Hudon 
and Jacques (4), Arcuri, Newman and Burstein (9) record the excellence of this drug as a topical anaesthetic agent. Burstein demonstrated that topical anaesthesia with 5 per cent Cyclaine spray prevented electrocardiographic changes in much the same proportion of patients as did the administration of procaine and its derivatives, but further that in some cases the drug actually reversed arrhythmias produced by anaesthesia.

I have personally used the drug in sixty cases for the introduction of an endotracheal tube under pentothal anaesthesia alone, and have found uniformly that if the larynx and trachea are adequately sprayed with 5 per cent solution of Cyclaine, using 2 to $4 \mathrm{cc}$., that an endotracheal tube may be inserted with no reaction of any kind from the patient in three to five minutes. I have employed the drug successfully on one occasion to relieve laryngeal spasm following laryngoscopy. The drug has also been employed for introduction of an endotracheal tube by other members of the staff in many cases, and found to be satisfactory. It has been used for topical anaesthesia for bronchograms with complete satisfaction and on the otolaryngology service for bronchoscopic examinations. There has been no evidence of a toxic reaction of any kirod in these patients.

\section{SUMMary}

From our experience Hexylcaine would appear to be a useful local anaesthetic agent having the advantages of low relative toxicity, prolonged and rapid action, and excellent topical anaesthetic properties.

\section{RÉSUMÉ}

Malgré le grand nombre de drogues anesthésiques locales efficaces déjà disponibles sur le marché, l'on continue de rechercher des drogues plus puissantes, à action plus prolongée, à faible toxicité et absence d'irritation du tissu. Une des substances les plus récentes qui s'offre comme anesthésie locale est l'Hexylcaïne (Cyclaïne). La Cyclaïne est quatre fois aussi puissante que la Procaïne et trois fois aussi toxique dans des expériences de laboratoire, donnant un rapport médicamenteux plus favorable que celui de la Procaïne. L'auteur s'est servi de la Cycläne en solution de $1 \%$ pour l'anesthésie régionale dans 168 cas, en dosages allant jusqu'à $30 \mathrm{mg}$ pour l'anesthésie lombaire et en solution de 5\% pour l'anesthésie topique du larynx et de la trachée avant l'intubation endotrachéale dans 54 cas avec des résultats tout à fait satisfaisants. Aucunes réactions toxiques majeures ne se sont déclarées et les troubles cardio-vasculaires secondaires ont été rares. L'anesthésie régionale a duré jusqu’à cinq heures et l'anesthésie lombaire environ une heure et demie. La "Cyclainne" semble être un agent anesthésique local utile, à toxicité relativement faible, à action prolongée et rapide et possédant d'excellentes propriétés anesthésiques topiques.

\section{REFERENCES}

1. Hancock, E. M., Hardy, E. M., Heyl, D., Whight, M. E. łand Cope, A. C. Aminoesters. J. Am. Chem. Soc. 66:1747 (1944).

2. KunA, S. \& Seeler, A. O. Studies on Local Anaesthetic 'Properties of 131 Alkylamino Alcohols and their Esters. J. Am. Chem. Soc. 90:181 (1947). 
3. Beyer, K. H., Latven, A. R., Freyburger, W. A. and Parker, Ma. P. A Comparative Study of the Activity and Toxicity of Hexylcaine (1-cyclohexylamino-2-propvlhenzoate); A New Local Anesthetic Agent. J. Pharm. \& Exper. Therap. 93:388 (1948).

4. Hudon, F. \& Jacques, A. Clinical Studies on "Cyclaine." Proc. Canad. Anaes. Soc. 1:34 (1952).

5. Orkin, L. R. \& Rovenstine, E. A. Hexylcaine (Cyclaine): Usefulness in Regional and Topical Anaesthesia-Preliminary Report. Anesthesiology 13:465 (1952).

6. Crawrond, O. B. Comparative Qualities of Three New Local Anesthetic Drugs: Xylocaine, Cyclaine, and Pravocaine. Anesthesiology 14:465 (1952).

7. Ruben, J. E. \& Anderson, E. Hexylcaine Hydrochloride. Am. J. Surg. 78:843 (1949).

8. RoY, E. S. \& Vinson, P. P. Hexylcaine-A New Topical Anesthetic Agent. Anesthesiology $14: 315$ (1953).

9. Arcuri, R. A., Newman, W., and Burstein, C. L. Electrocardiographic Studies during Endotracheal Intubation; V, Effects during General Anaesthesia and Hexylcaine Hydrochloride Topical Spray. Anesthesiology 14:46 (1953). 